\title{
Localization of Cystic Fibrosis Transmembrane Conductance Regulator mRNA in the Human Gastrointestinal Tract by In Situ Hybridization
}

\author{
Theresa V. Strong, ${ }^{* *}$ Karina Boehm, ${ }^{*}$ and Francis S. Collins ${ }^{* *}$ \\ Departments of *Human Genetics and ${ }^{*}$ Internal Medicine, The University of Michigan Medical Center, Ann Arbor, Michigan 48109- \\ 0650; and ${ }^{\S}$ The National Center for Human Genome Research, The National Institutes of Health, Bethesda, Maryland 20892
}

\begin{abstract}
We have used in situ hybridization to localize expression of the cystic fibrosis transmembrane conductance regulator (CFTR) gene in the human gastrointestinal tract and associated organs. The stomach exhibits a low level of CFTR expression throughout gastric mucosa. In the small intestine, expression is relatively high in the mucosal epithelium, with a decreasing gradient of expression along the crypt to tip axis. The cells of the Brunner's glands express high levels of CFTR mRNA. In addition, there is a small subpopulation of highly positive cells scattered along the epithelium in the duodenum and jejunum, but not in the ileum. These cells do not represent endocrine cells, as determined by lack of colocalization with an endocrine-specific marker. The distribution of CFTR mRNA in the colon is similar to the small intestine, with highest level of expression in the epithelial cells at the base of the crypts. In the pancreas, CFTR is expressed at high levels in the small, intercalated ducts and at lower levels in the interlobular ducts. CFTR transcripts are expressed at uniformly high levels in the epithelium of the gallbladder. Throughout the gastrointestinal tract, CFTR expression is increased in mucosal epithelial cells that are near lymph nodules. (J. Clin. Invest. 1994. 93:347-354.) Key words: cystic fibrosis • expression • intestine $\bullet$ chloride secretion • epithelia
\end{abstract}

\section{Introduction}

Cystic fibrosis $(\mathrm{CF})^{1}$ is a common genetic disease characterized clinically by chronic obstructive pulmonary disease, insufficient pancreatic exocrine function, intestinal malabsorption, and elevated sweat electrolyte levels $(1,2)$. CF is caused by mutations in the cystic fibrosis transmembrane conductance regulator (CFTR) gene (3-5), which encodes a membrane-associated chloride $\left(\mathrm{Cl}^{-}\right)$channel $(2,6,7)$. By Northern blot analysis, the CF gene is expressed at variable levels in epithelial tissues and cells lines, and is particularly highly expressed in the colonic epithelial cell line T84 (4). At the cellular level, CFTR dysfunction results in defective cAMP-regulated $\mathrm{Cl}^{-}$conductance, primarily in cells of epithelial origin $(8,9)$. This disrupts transepithelial $\mathrm{Cl}^{-}$secretion, which is critical for the produc-

Address correspondence to Dr. Francis S. Collins, Building 38A, Room 605, 9000 Rockville Pike, Bethesda, MD 20892.

Received for publication 16 April 1993 and in revised form $30 \mathrm{Au}$ gust 1993.

1. Abbreviations used in this paper: CF, cystic fibrosis; CFTR, cystic fibrosis transmembrane conductance regulator.

The Journal of Clinical Investigation, Inc.

Volume 93, January 1994, 347-354 tion of properly hydrated secretions. As a result, many exocrine organs become clogged with thick, inspissated secretions. In the lung, the unusually viscous nature of the secretions is associated with chronic infections, airway obstruction, and, eventually, respiratory failure.

Although lung disease is the primary cause of mortality in CF patients today, a significant proportion of the morbidity of the disease is directly related to gastrointestinal complications $(1,10)$. Obstruction of pancreatic ducts by hyperconcentrated secretions results in destruction of the pancreas and insufficient delivery of pancreatic enzymes. Oral enzyme supplementation is necessary for $\sim 85 \%$ of patients. Another common complication is intestinal obstruction. In $5-10 \%$ of $C F$ cases this is the presenting symptom, occurring in newborns as meconium ileus. A similar blockage, distal intestinal obstruction, occurs in $>20 \%$ of adult patients (11). CF patients also face an increased incidence of liver disease characterized by focal biliary cirrhosis $(12,13)$, and an increased incidence of gallbladder disease compared with the normal population $(14,15)$. Other gastrointestinal disturbances include dilation of the duodenal Brunner's glands (16) and small bowel changes evident by radiographic studies (17).

The recently developed transgenic CF mouse models also demonstrate significant pathology in the gastrointestinal tract $(18,19)$. In one transgenic line, gastrointestinal complications represent the primary cause of mortality (18). The extensive pathology in the gastrointestinal tract and accessory organs of humans and mice suggests a critical role for CFTR in maintaining proper ion and water balance throughout the digestive system. Characterization of the specific cell types that express CFTR in vivo is an important step in elucidating the normal role of this protein and understanding the pathological basis of the disease, particularly in distinguishing the pathological findings that are due to a primary defect from those that arise from the secondary effects of pancreatic insufficiency and malabsorption. We therefore investigated the expression of CFTR mRNA in the human gastrointestinal tract, where it was found to be expressed in a complex and precisely regulated manner.

\section{Methods}

Sample preparation. Tissue samples were obtained from surgical specimens, and primarily represented samples of normal tissue removed during resections of benign and malignant neoplasms. Samples used in the in situ studies were taken from outside the margins of abnormal tissue and appeared histologically normal when examined by light microscopy. The exception was the gallbladder samples, which were removed due to cholecystitis. Tissue samples were immediately frozen by immersion in cold $\left(-30^{\circ} \mathrm{C}\right)$ isopentane or embedded in OCT and frozen in the same manner. Frozen sections $(6-8 \mu \mathrm{m})$ were mounted onto poly (L-lysine)-coated slides and stored at $-70^{\circ} \mathrm{C}$ until used.

In situ hybridization. Sections were fixed in freshly prepared $4 \%$

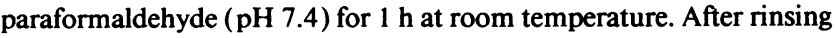


in $2 \times \mathrm{SSC}$, the sections were incubated with $1 \mu \mathrm{g} / \mathrm{ml}$ proteinase $\mathrm{K}$ for $10 \mathrm{~min}$ at $37^{\circ} \mathrm{C}$, then treated with $0.25 \%$ acetic anhydride in $0.1 \mathrm{M}$ triethanolamine (TEA) $(\mathrm{pH} \mathrm{8.0)}$ for $10 \mathrm{~min}$, and dehydrated through a graded ethanol series. As a control for nonspecific binding of the antisense probe to tissue, some sections were treated with $100 \mu \mathrm{g} / \mathrm{ml}$ $\mathrm{RNase} A$ for $1 \mathrm{~h}$ at $37^{\circ} \mathrm{C}$ before incubation in proteinase $\mathrm{K}$.

Antisense and sense ${ }^{35} \mathrm{~S}$-labeled cRNA probes specific for the $\mathbf{R}$ domain of CFTR (base pairs 1900-2770) were prepared by an in vitro transcription reaction using $\mathrm{T} 7$ or $\mathrm{T} 3$ polymerase (GIBCO BRL, Gaithersburg, MD). The reaction included $100 \mu \mathrm{Ci}$ of UTP and $50 \mu \mathrm{Ci}$ of CTP $(1,000-1,500 \mathrm{Ci} / \mathrm{mmol}$; New England Nuclear, Boston, MA), $1 \mu \mathrm{g}$ of linearized plasmid, $0.5 \mathrm{mM}$ ATP, $0.5 \mathrm{mM} \mathrm{GTP}, 0.4 \mathrm{mM} \mathrm{CTP}$, and $15 \mathrm{mM}$ DTT, in a reaction buffer provided by the manufacturer. The radiolabeled probes were hydrolyzed to $\sim 100-300$ nucleotides in length to increase the permeability.

Sections were hybridized overnight at $55^{\circ} \mathrm{C}$ with $7 \times 10^{7} \mathrm{cpm} / \mathrm{ml}$ of probe corresponding to the antisense or, as a control, the sense strand. The probe was diluted in a hybridization solution that consisted of $75 \%$ formamide, $3 \times$ SSC, $0.2 \mathrm{mg} / \mathrm{ml}$ tRNA, $1 \times$ Denhardt's solution, 50

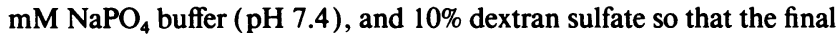
concentration of formamide was $60-65 \%$; and DTT was added to a final concentration of $10 \mathrm{mM}$. After hybridization, coverslips were removed and the slides were washed three times in 2x SSC at room temperature, and then in 50\% formamide, $2 \times$ SSC, $25 \mathrm{mM}$ DTT for 20 min at $60^{\circ} \mathrm{C}$. After this high stringency wash, the slides were rinsed in a buffer of $10 \mathrm{mM}$ Tris-Cl (pH 7.5), $5 \mathrm{mM}$ EDTA, $0.4 \mathrm{M} \mathrm{NaCl}$ and treated with RNase $A(60 \mu \mathrm{g} / \mathrm{ml})$ in the same buffer for $1 \mathrm{~h}$ at $37^{\circ} \mathrm{C}$. The slides were then washed in buffer alone for $15 \mathrm{~min}$ and finally washed for $2-4 \mathrm{~h}$ at $37^{\circ} \mathrm{C}$ in a $50 \%$ formamide, $2 \times$ SSC, $10 \mathrm{mM}$ DTT. After dehydration through a graded ethanol series, slides were hand dipped in NTB-2 liquid emulsion (Kodak, Rochester, NY) and stored at $4^{\circ} \mathrm{C}$ in a light-tight box with desiccant for 5-14 d. The slides were developed in D-19 developer (Kodak) for $2 \mathrm{~min}$, rinsed with distilled water, immersed in Rapid Fixer for $3 \mathrm{~min}$, and again rinsed in water. Sections were stained with the nuclear stain toluidine blue $O(0.2 \%)$, dehydrated, and mounted. Silver grains were visualized by dark field microscopy using a Nikon Microphot-FXA microscope. The percent of infrequent, highly positive cells in the duodenum and jejunum sections was determined by counting a minimum of 10 fields and 3,500 cells.

Immunocytochemistry. Sections stained for chromogranin A first underwent in situ hybridization as described above. Before dipping the slides in photographic emulsion, the sections were rehydrated in Trisbuffered saline (TBS; $50 \mathrm{mM}$ Tris- $\mathrm{Cl}, \mathrm{pH} 7.5,0.9 \% \mathrm{NaCl}$ ). Endogenous peroxidase activity was quenched by immersion in $0.5 \% \mathrm{H}_{2} \mathrm{O}_{2}$ in methanol for $20 \mathrm{~min}$ at room temperature. Nonspecific binding was blocked through incubation with $0.1 \%$ BSA (crystalline grade; Sigma Chemical Co., St. Louis, MO) and 1.5\% normal horse serum for 30 min at $37^{\circ} \mathrm{C}$. A commercially available monoclonal antibody specific for chromogranin A (20) (Boeringher Mannheim Biochemicals, Indianapolis, IN) was incubated with the sections at a concentration of $10 \mu \mathrm{g} / \mathrm{ml}$ for $1 \mathrm{~h}$ at $37^{\circ} \mathrm{C}$ in TBS with $0.1 \%$ BSA. After washing in three changes of TBS, the antichromogranin localization was visualized using a Vectastain $\mathrm{ABC}$ immunoperoxidase system (Vector Laboratories, Burlington, $\mathrm{CA}$ ) with diaminobenzadine as the substrate according to the manufacturer's directions. After developing the reaction product, the sections were dehydrated and the slides were coated in emulsion, exposed, and developed as usual for in situ hybridization. Sections were stained with toluidine blue $\mathrm{O}$, and cells containing chromogranin contained a brown reaction product. As a control, some sections were incubated in BSA that did not contain the primary antibody. No reaction product was detected in these sections (not shown).

\section{Results}

In situ hybridization in the stomach and intestines. The pattern of CFTR expression in the stomach was studied using a cRNA probe (Fig. 1, $A-C$ ). CFTR is expressed at low levels throughout the gastric glands, including the mucous surface and neck cells, parietal cells, and chief cells. Expression is diffuse and no specific cell type expresses CFTR at high levels. There is no detectable expression in the underlying muscularis mucosa. Sections that were hybridized with the control CFTR sense cRNA probe (Fig. $1 C$ ), or those pretreated with RNase before hybridization with the antisense probe (data not shown), did not show any significant hybridization. The low levels of expression in the human stomach is consistent with studies of mouse CFTR (18), where expression in the stomach is much lower than in the intestines.

In contrast to the stomach, CFTR is expressed at relatively high levels in the intestinal epithelium (Fig. 1, D-L). Overall, expression is highest in the duodenum, decreases steadily through the small intestine, and is lowest in the colon. In all regions of the intestine, there is a decreasing gradient of CFTR expression along the crypt to villus tip axis, with expression of CFTR highest in the cells of the crypts. The signal in the crypts is uniformly high, suggesting that all cell types in the crypts, including goblet cells, Paneth cells, and undifferentiated epithelial cells, express similar levels of CFTR. Expression decreases toward the tips of the villi, and only a weak signal was detected in the top one-third of the villi.

The duodenum exhibits relatively high levels of CFTR mRNA in the mucosal epithelial cells (Fig. $1, D-F$ ), with the crypt cells expressing more CFTR than the villus cells. In addition, there are isolated cells scattered throughout the crypts and villi that express high levels of CFTR mRNA (Fig. $1 E$ ). These highly positive cells have a frequency of $\sim 1-2 \%$ of the cells along the epithelium, and are present both in the crypts and along the villi, but are more often found on villi. The cells of the Brunner's glands also express high levels of CFTR mRNA (Fig. $1 E$ ). Expression is uniformly high in these gland cells.

A pattern of expression similar to the duodenum is apparent in the jejunum (Fig. 1, G-I). Again, expression is highest in the epithelial cells of the crypts and decreases towards the tips, except for the isolated, highly positive cells. The highly positive cells are slightly less numerous in the jejunum, comprising $\sim 0.5 \%$ of the epithelial cells. As in the duodenum, CFTR transcripts are not detectable in the submucosa.

CFTR exhibits a similar pattern of expression in the ileum (Fig. $1, J-L$ ) and colon (Fig. $1, M-O$ ). In both cases CFTR expression is highest in the lowest one-third of the crypts, is decreased but detectable in the middle one-third, and is undetectable in the top one-third of epithelial cells. The highly positive cells present in the duodenum and jejunum are absent from the ileum and colon.

Analysis of highly positive intestinal epithelial cells. The epithelial cells expressing high levels of CFTR mRNA in the duodenum and jejunum were studied further to determine if they belonged to a previously described subset of intestinal epithelial cell. When visualized by light microscopy, these cells are located primarily along the epithelial cell layer and are not morphologically distinct from the columnar epithelial cells present in the crypts and villi. They appear distinct from goblet cells, however, as they lack apical mucous cups and do not have flattened, basally located nuclei. The frequency and distribution of the highly positive cells are most consistent with that described for certain subsets of enteroendocrine cells, for example, those that secrete secretin, gastric inhibitory peptide, or cholecystokinin (21). To determine if these cells are in fact 

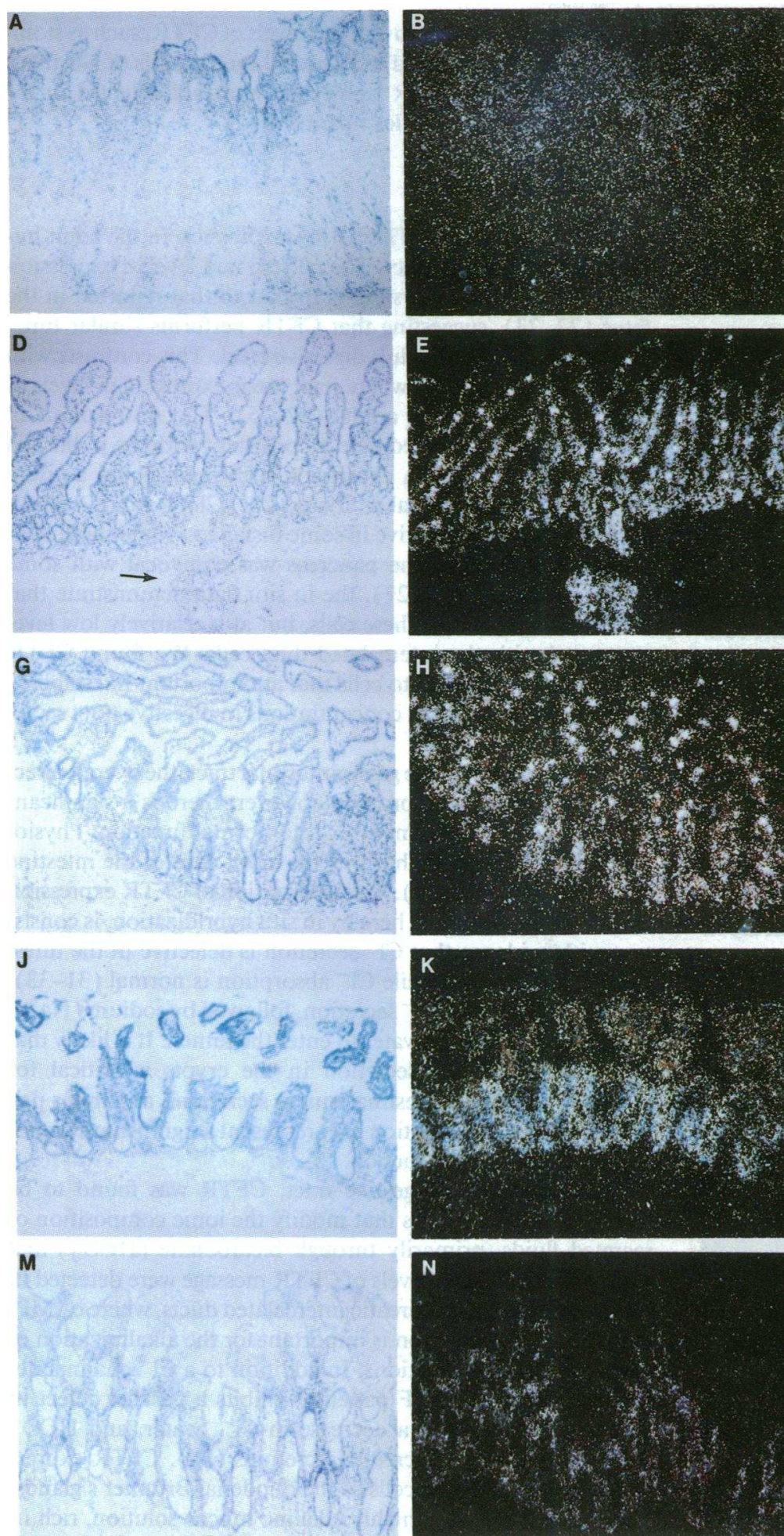

N
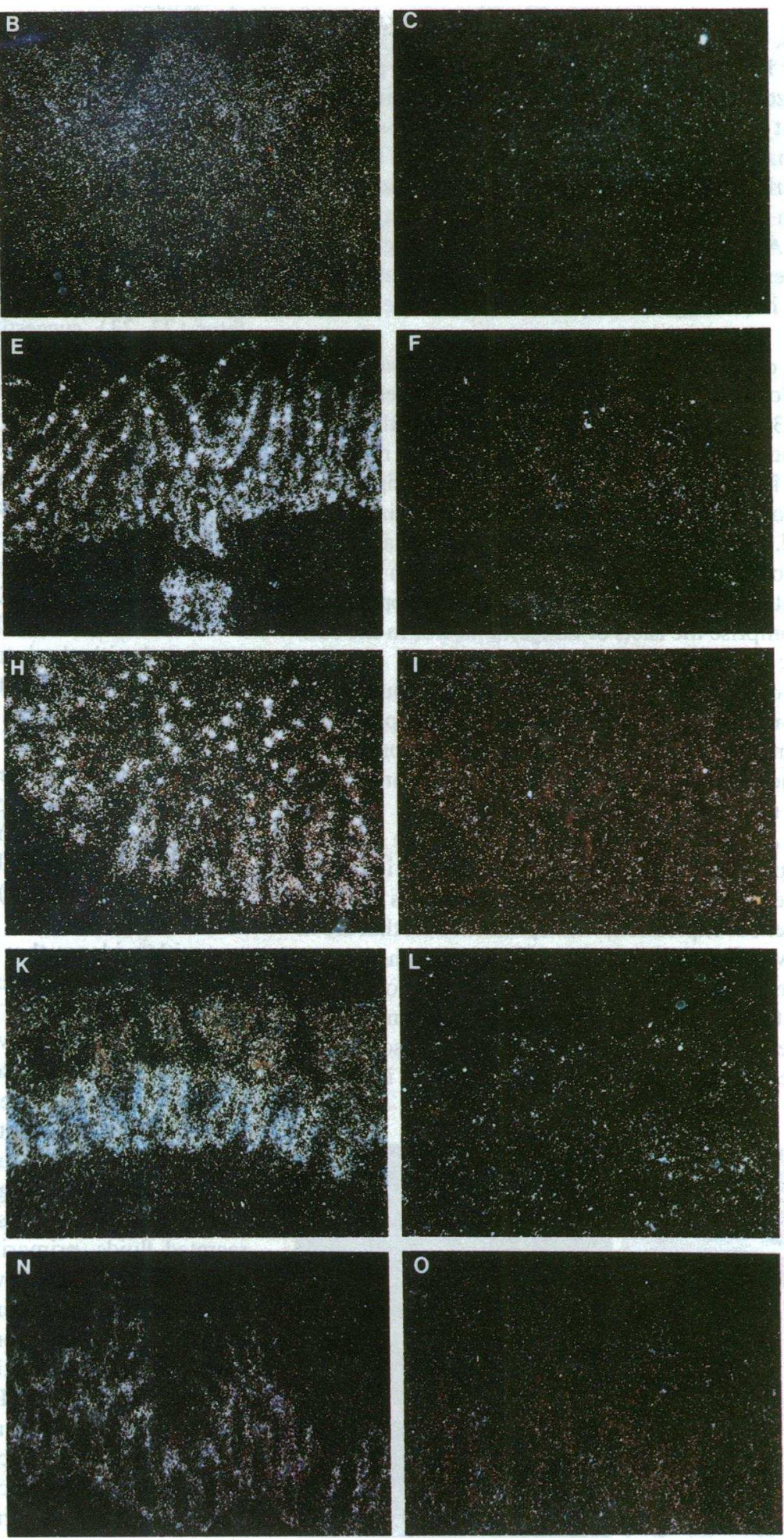

Figure 1. Hybridization of a ${ }^{35}$ S-labeled CFTR cRNA in stomach and intestine tissue sections. (Left) Bright field photomicrograph of the tissue hybridized with an antisense probe; (middle) the same field visualized with dark field optics so that the antisense signal is seen as silver grains; and ( right) an adjacent section hybridized with the control (sense) cRNA probe and visualized by dark field microscopy. $(A-C)$ Stomach $(\times 60)$. A low level of hybridization is found throughout the gastric mucosa. $(D-F)$ Duodenum $(\times 60)$. The level of expression decreases along the crypt to tip axis, with the exception of infrequent highly positive cells. These cells are found predominantly along the epithelial lining of the villi and, less frequently, the crypts. Very rarely, a highly positive cell appeared to be located in the lamina propria. An arrow indicates the location of a Brunner's gland. $(G-I)$ Jejunum $(\times 80)$. The pattern of expression is similar to the duodenum, except that the frequency of the highly positive cells is lower. $(J-L)$ Ileum $(\times 80)$. No highly positive cells are apparent in the final portion of the small intestine. $(M-O)$ Colon $(\times 80)$. Expression is highest in the base of the crypts. 
endocrine cells, we performed immunocytochemistry on sections after they had been hybridized with the CFTR probe. A well-characterized antibody specific for chromogranin, a protein component of the secretory membrane vesicles, was used. This antibody has been shown to react with all known subtypes of enteroendocrine cells (20). The CFTR mRNA and the antichromogranin antibody reaction product were visualized at the same time. As demonstrated in Fig. 2, the cells highly positive for CFTR expression are different from those that express chromogranin, indicating that they do not represent enteroendocrine cells.

Expression of CFTR in the pancreas. As expected on the basis of pathology, CFTR is expressed at high levels in the pancreas (Fig. 3, $A-C$ ). The signal was strongest in the small, intercalated ducts that connect the acini, although no signal was detectable in the acinar cells themselves. The signal was decreased, although still readily detectable, as the size of the ducts increased. Expression of CFTR in the epithelial cells of the large, interlobular ducts was found to be less than half that of the intercalated ducts cells. No expression was apparent in the cells that comprise the islets of Langerhans, nor in the connective tissue.

Expression of CFTR in gallbladder. CFTR was found to be expressed at uniformly high levels in the columnar epithelium lining the lumen of the gallbladder (Fig. 3, $D-F$ ). Expression is limited to epithelial cells and appears to be similar throughout the gallbladder neck and body.

Expression of CFTR near lymph nodules. In the stomach and intestinal epithelia, CFTR expression is increased in epithelial cells that are in close proximity to lymph nodules (Fig. 4). There is a gradient of expression, with epithelial cells that are in direct contact with lymph nodule tissue expressing the highest level of message, and a gradual decrease in the level of expression in cells that are located further away from the lymph nodule. The degree of increase in CFTR mRNA was somewhat variable between samples and was best appreciated in tissues
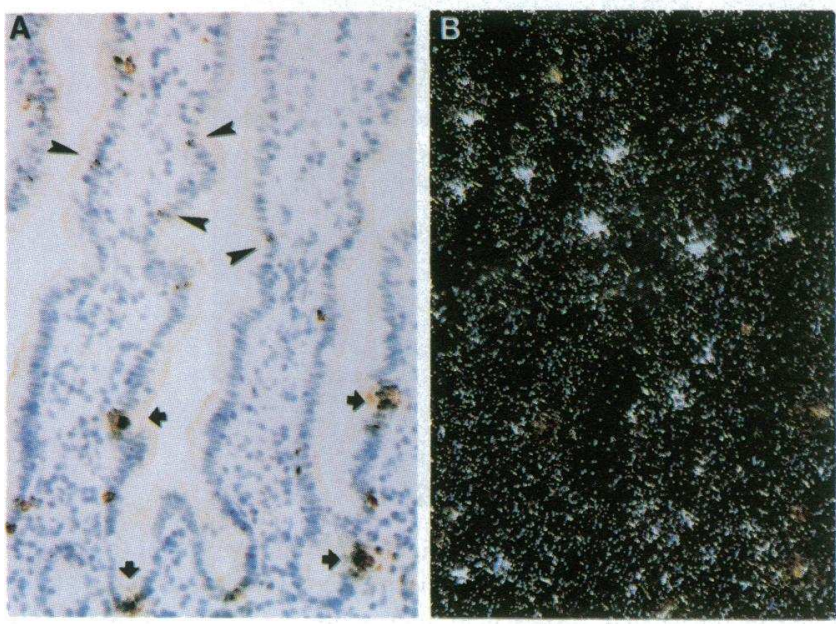

Figure 2. Localization of CFTR mRNA and chromogranin protein in the small intestine. Bright field $(A)$ and dark field $(B)$ photomicrographs of duodenal sections that were hybridized with a CFTR antisense probe and stained with an endocrine-specific antibody. Some of the cells highly positive for CFTR expression are indicated by the arrowheads in $A$, and are seen as bright spots in $B$, while several cells positive for chromogranin (brown reaction product) are indicated with arrows $(\times 200)$. that expressed comparatively low levels of CFTR, such as stomach and colon. As would be expected on the basis of Northern blot analysis (4), CFTR transcripts were not detected in the cells of the lymph nodules themselves.

\section{Discussion}

We have examined CFTR mRNA expression in the adult human gastrointestinal tract. The pattern and level of expression in the adult digestive system is similar to that reported in the fetus $(22,23)$, suggesting that CFTR performs similar functions in the fetal and adult digestive tract. This contrasts with the respiratory system, where fetal lungs express high levels of CFTR compared with adults (22-25). The distribution of CFTR message described here is consistent with the published data for CFTR protein expression using polyclonal antisera $(26,27)$ or a monoclonal antibody (28). CFTR mRNA detection may be more sensitive in some instances; while staining of interlobular ducts of the pancreas was equivocal with some CFTR antibodies $(26,27)$, the in situ data demonstrate that CFTR is expressed in these cells, but at a relatively low level compared with the intercalated duct cells. We found CFTR mRNA to be localized to cells that are important in establishing proper fluid and ion concentrations in digestive tract secretions.

As fluid traverses the gastrointestinal tract, the overall direction of $\mathrm{Cl}^{-}$flow is absorptive; however, there is a significant $\mathrm{Cl}^{-}$secretory component critical to normal function. Physiological studies suggest that it is the crypt cells of the intestine that secrete $\mathrm{Cl}^{-}(29,30)$. The localization of CFTR expression to this region, as shown here by in situ hybridization, is consistent with evidence that $\mathrm{Cl}^{-}$secretion is defective in the intestines of CF patients while $\mathrm{Cl}^{-}$absorption is normal (31-33). Epithelial cell apical $\mathrm{Cl}^{-}$secretion, followed by sodium $\left(\mathrm{Na}^{+}\right)$, is the driving force for water to enter the lumen. It is likely that CFTR-mediated $\mathrm{Cl}^{-}$secretion in the crypts is critical for proper hydration of intestinal mucus secretions, and that a primary defect in $\mathrm{Cl}^{-}$secretion may represent a significant component of intestinal obstruction.

Throughout the digestive tract, CFTR was found to be highly expressed in cells that modify the ionic composition of secreted fluids, primarily through bicarbonate $\left(\mathrm{HCO}_{3}^{-}\right)$and water secretion. High levels of CFTR message were detected in regions such as the pancreatic intercalated ducts, where cAMPinduced $\mathrm{HCO}_{3}^{-}$secretion is important for the alkalinization of pancreatic acinar secretions. In addition to a $\mathrm{Cl}^{-}$channel defect, the pancreas of $\mathrm{CF}$ patients exhibits a parallel defect in $\mathrm{HCO}_{3}^{-}$secretion, with a decrease in $\mathrm{Cl}^{-}$, water, and $\mathrm{HCO}_{3}^{-}$ measurable in the pancreatic secretions (34). CFTR expression is also high in the cells of the duodenal Brunner's glands. These glands secrete a highly alkaline mucus solution, rich in bicarbonate ions, that acts along with the secretions of the pancreas to neutralize the stomach contents and protect the mucosal epithelium. Localization of CFTR to cells important in alkalinizing and hydrating secretions is consistent with a model of $\mathrm{Cl}^{-}$secretion in these tissues in which cAMP-stimulated $\mathrm{Cl}^{-}$ efflux drives $\mathrm{HCO}_{3}^{-}$secretion via an anion exchanger. In this model, secreted $\mathrm{Cl}^{-}$is reabsorbed by the cell in exchange for $\mathrm{HCO}_{3}^{-}$, which is secreted into the lumen $(26,30,34)$. cAMPstimulated primary active proton transport across the basolateral membrane or basolateral $\mathrm{Na}^{+}-\mathrm{HCO}_{3}^{-}$symport may represent additional driving forces for $\mathrm{Cl}^{-}$secretion and $\mathrm{Cl}^{-} / \mathrm{HCO}_{3}^{-}$ 

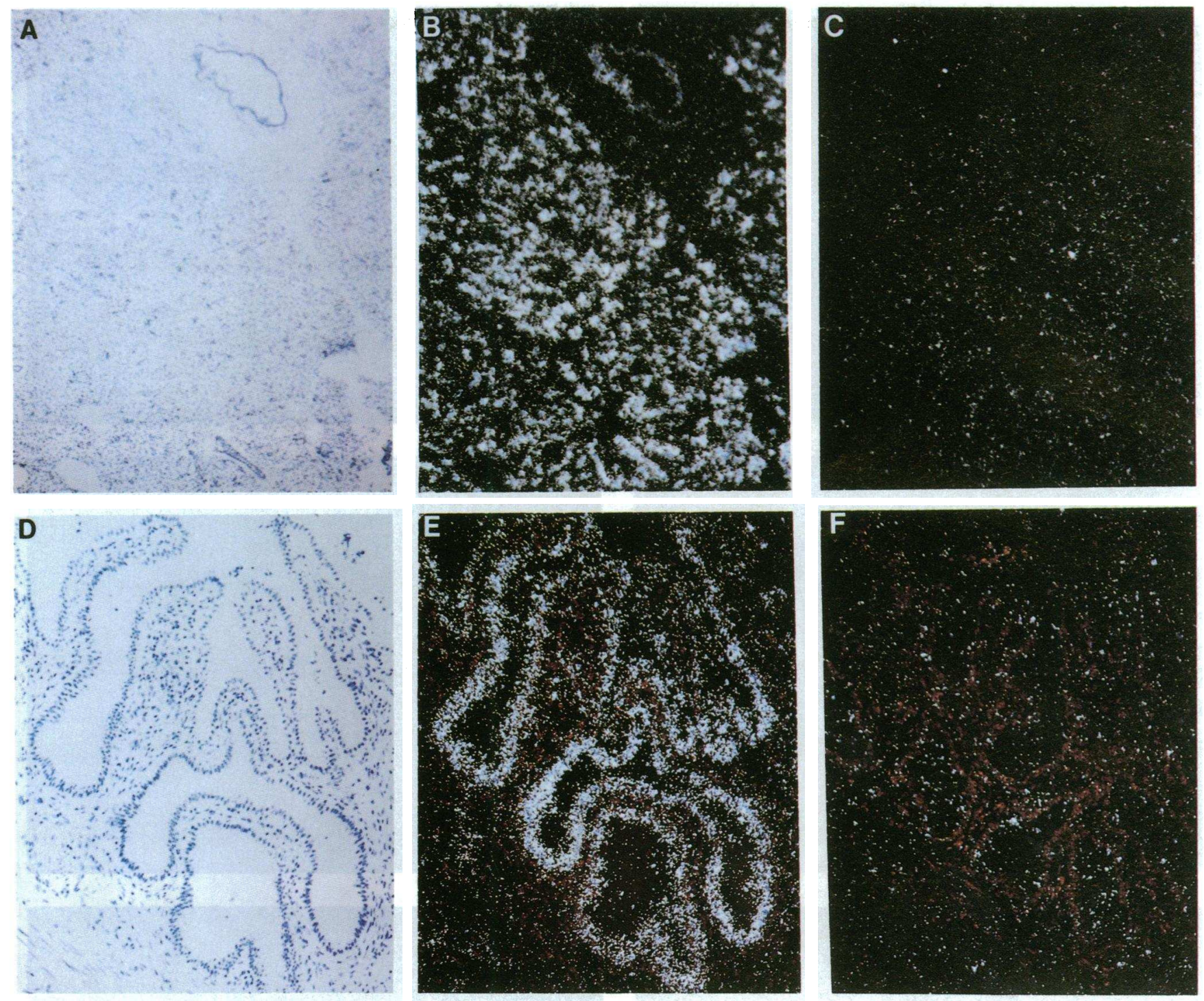

Figure 3. Localization of CFTR message in the pancreas $(A-C)$ and gallbladder $(D-F)$. Bright field $(A)$ and dark field $(B)$ photomicrographs of pancreatic sections hybridized with a CFTR antisense probe. The strong signal is localized to small, intercalated ducts. An interlobular duct surrounded by connective tissue is located in the top right hand corner of the field. $(C)$ An adjacent section hybridized with the sense cRNA probe and viewed with darkfield optics $(\times 60)$. Bright field $(D)$ and dark field $(E)$ photomicrographs of gallbladder sections hybridized with an antisense probe. Expression is detected in the epithelial cells. $(F)$ Dark field photomicrograph of an adjacent section hybridized with the sense probe. $(\times 100)$.

exchange at the apical membrane (35). We have shown elsewhere (35a) that CFTR mRNA is also highly expressed in the bile duct cells of the liver, where a similar alkalinization and hydration of bile secretions occurs.

The role of CFTR in the gallbladder, generally thought of as salt-absorptive epithelium, is less clear. Clinically, $>40 \%$ of CF patients have signs of gallbladder disease (15), and CF patients at all levels of pancreatic function have decreased bile acid and water output from the gallbladder (36), suggesting a primary defect may be present. In addition, a cAMP-stimulated apical $\mathrm{Cl}^{-}$conductance has been described in the gallbladder of mammals and amphibians, and is associated with inhibition of fluid and salt absorption $(37,38)$. The high level of CFTR expression in gallbladder epithelium suggests that CAMP-stimulated apical $\mathrm{Cl}^{-}$secretion may contribute significantly to the modification and/or release of gallbladder contents. A better under- standing of the functional role of $\mathrm{Cl}^{-}$conductance in the gallbladder will be necessary to determine the basis of pathology in CF patients.

Infrequent cells in the intestine epithelia of the duodenum and jejunum were found to express very high levels of CFTR. These cells had morphological characteristics that were inconsistent with goblet cells, but were otherwise indistinguishable from columnar epithelial cells. The presence of cells highly positive for CFTR has been documented in the rat small intestine (39), but they were not found in the mouse jejunum ( T. V. Strong, unpublished results). Although the frequency and distribution of the highly positive cells are most consistent with that of a subclass of enteroendocrine cells, an endocrine-specific cell marker did not colocalize with CFTR mRNA, indicating that the highly positive cells are not endocrine cells. Another relatively infrequent cell type in the intestinal epithelia is 

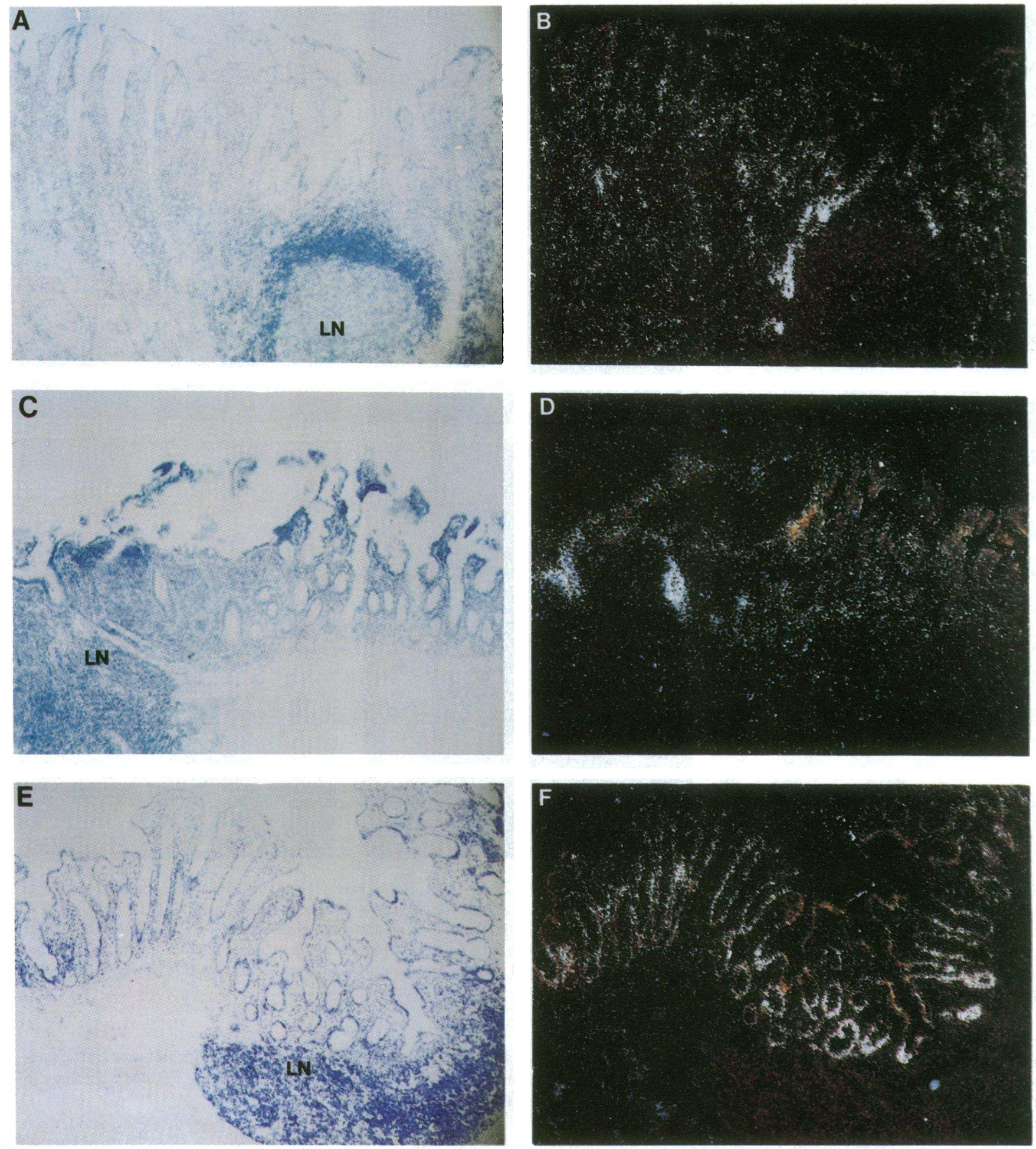

Figure 4. Increased expression of CFTR near lymph nodules. Bright field $(A, C$, and $E)$ and dark field $(B, D$, and $F)$ photomicrographs of stomach $(A$ and $B)$, ileum $(C$ and $D)$, and colon $(E$ and $F)$ tissue sections hybridized with the antisense probe. In each bright field panel, the location of a lymph nodule is evident by the dense population of nuclei $(L N)$. Those epithelial cells near the lymph nodule have a higher level of CFTR mRNA signal compared with the cells not in close approximation to the lymph nodule $(\times 60)$.

the Tuft or caveolated cell $(40,41)$. However, Tuft cells have been identified throughout the gastrointestinal tract of humans, mice, and rats, whereas the cells highly positive for CFTR are limited to the duodenum and jejunum of humans and rats. The highly positive cells may therefore represent a previously unappreciated subclass of epithelial cells that express high levels of CFTR and have a specialized role in $\mathrm{Cl}^{-}$ secretion, or an alternative CFTR function. It should be noted that highly positive cells of approximately the same frequency have also been identified among the epithelial cells that line 
ciliated and collecting ducts of the bronchial submucosal glands (24). It remains to be determined if these cells are functionally similar.

Unexpectedly, expression of CFTR in the epithelial cells is increased when the cells are in close approximation to lymph nodules. As would be expected on the basis of Northern analysis (4), CFTR signal was not detected in the lymph nodules themselves, but in the epithelial cells that were adjacent to the lymph nodules. It is possible that the epithelial cells overlying lymph nodules are intrinsically different from those that are not. Alternatively, a diffusible factor produced by the lymph nodule may act to increase the rate of CFTR transcription or stabilize CFTR mRNA in the nearby epithelial cells. Several exogenous factors, including cAMP analogues (42), divalent cations (43), phorbol esters (44), and estrus cycle specific factors (45), have been shown to regulate the level of CFTR expression. Further studies are necessary to delineate the mechanism underlying the increased CFTR expression in these cells.

As shown here, CFTR is expressed in many digestive tract organs that demonstrate, to a varying degree, pathology in CF patients, including the pancreas, gallbladder, and small and large intestines. Although CFTR may perform additional functions $(46,47)$, it is likely that the primary role of CFTR in the digestive system is as $\mathrm{Cl}^{-}$channel. Studies of the pathophysiology of CF indicate that proper CFTR function is of prime importance in the hydration of secretions and may secondarily affect secretion of $\mathrm{HCO}_{3}^{-}$, and perhaps other anions (48). Although it is clear that environmental factors such as diet and enzyme supplementation therapy influence the extent of pathology in the gastrointestinal tract, the localization of CFTR to epithelial cells, which play a crucial role in the modification of digestive tract secretions, suggests that disruption of CFTR function may be the direct cause of disease in these organs.

\section{Acknowledgments}

We thank Drs. Stanley Watson and Susan Wilson-Gunn for advice in developing the in situ hybridization techniques, and Drs. Jim Wilson and Rebecca Van Dyke for helpful discussions. We also thank Sonia Janich and the Cell Morphology Core of the Cystic Fibrosis Foundation Research Development Program for technical assistance.

T. V. Strong is a Cystic Fibrosis Foundation Postdoctoral Fellow and F. S. Collins was an Investigator in the Howard Hughes Medical Institute. This work was supported by National Institutes of Health grants DK-39690 and DK-42718 to F. S. Collins, and Cystic Fibrosis Foundation Research Development grant R475.

\section{References}

1. Boat, T. F., M. J. Welsh, and A. L. Beaudet. 1989. Cystic fibrosis. In The Metabolic Basis of Inherited Disease. C. R. Scriver, A. L. Beaudet, W. S. Sly, and D. Valle, editors. McGraw-Hill Inc., New York. 2649-2680.

2. Collins, F. S. 1992. Cystic fibrosis: molecular biology and therapeutic implications. Science (Wash. DC). 256:774-779.

3. Rommens, J. M., M. C. Iannuzzi, B.-S. Kerem, M. L. Drumm, G. Melmer, M. Dean, M. Zsiga, M. Buchwald, J. R. Riordan, L.-C. Tsui, and F. S. Collins. 1989. Identification of the cystic fibrosis gene: chromosome walking and jumping. Science (Wash. DC). 245:1059-1065.

4. Riordan, J. R., J. M. Rommens, B.-S. Kerem, N. Alon, R. Rozmahel, Z. Grzelczak, J. Zielenski, S. Lok, N. Plavsic, J.-L. Chou, M. L. Drumm, M. C. Iannuzzi, F. S. Collins, and L.-C. Tsui. 1989. Identification of the cystic fibrosis gene: cloning and characterization of the complementary DNA. Science (Wash DC). 245:1066-1073.

5. Kerem, B.-S., J. M. Rommens, J. A. Buchanan, D. Markiewicz, T. K. Cox, A. Chakravarti, M. Buchwald, and L.-C. Tsui. 1989. Identification of the cystic fibrosis gene: genetic analysis. Science (Wash. DC). 245:1073-1080.

6. Bear, C. E., C. Li, N. Kartner, R. J. Bridges, T. J. Jensen, M. Ramjeesingh, and J. Riordan. 1992. Purification and functional reconstitution of the cystic fibrosis transmembrane conductance regulator (CFTR). Cell. 68:809-818.

7. Welsh, M. J., M. P. Anderson, D. P. Rich, H. A. Berger, G. M. Denning, L. S. Ostedgaard, D. N. Sheppard, S. H. Cheng, R. J. Gregory, and A. L. Smith. 1992. Cystic fibrosis transmembrane conductance regulator: a chloride channel with novel regulation. Neuron. 8:821-829.

8. Quinton, P. M. 1990. Cystic fibrosis: a disease in electrolyte transport. FASEB (Fed. Am. Soc. Exp. Biol.) J. 4:2709-2717.

9. Anderson, M. A., D. N. Sheppard, H. A. Berger, and M. J. Welsh. 1992. Chloride channels in the apical membrane of normal and cystic fibrosis airway and intestinal epithelia. Am. J. Physiol. 263:L1-14.

10. Park, R. W., and R. J. Grand. 1981. Gastrointestinal manifestations of cystic fibrosis: a review. Gastroenterology. 81:1143-1161.

11. Di Sant'Agnese, P. A., and P. B. Davis. 1979. Cystic fibrosis in adults: 75 cases and a review of 232 cases in the literature. Am. J. Med. 66:121-132.

12. Di Sant'Agnese, P. A., and W. A. Blanc. 1956. A distinctive type of biliary cirrhosis of the liver associated with cystic fibrosis of the pancreas. Pediatrics. 18:387-409.

13. Scott-Jupp R., M. Lama, and M. S. Tanner. 1991. Prevelance of liver disease in cystic fibrosis. Arch. Dis. Child. 66:698-701.

14. Oppenheimer, E. H., and J. R. Esterly. 1975. Pathology of cystic fibrosis: review of the literature and comparison with 146 autopsied cases. Perspect. Pediatr. Pathol. 2:241-278.

15. L'Heureux, P. R., J. N. Isenberg, H. L. Sharp, and W. J. Warwick. 1977. Gallbladder disease in cystic fibrosis. Am. J. Roentgenol. Radium Ther. Nucl. Med. 128:953-956.

16. Oppenheimer, E. H., and J. R. Esterly. 1973. Cystic fibrosis of the pancreas: Morphologic findings of infants with and without pancreatic lesions. Arch. Pathol. 96:149-154.

17. Taussig, L. M., R. M. Saldino, and P. A. di Sant'Agnese. 1973. Radiographic abnormalities of the duodenum and small bowel in cystic fibrosis of the pancreas (mucoviscidosis). Radiology. 106:369-376.

18. Snouwaert, J. N., K. K. Brigman, A. M. Latour, N. N. Malouf, R. C. Boucher, O. Smithies, and B. H. Koller. 1992. An animal model for cystic fibrosis made by gene targeting. Science (Wash. DC). 257:1083-1088.

19. Dorin, J. R., P. Dickinson, E. W. F. W. Alton, S. N. Smith, D. M. Geddes, B. J. Stevenson, W. L. Kimber, S. Fliming, A. R. Clarke, M. L. Hooper, L. Anderson, R. S. P. Beddington, and D. J. Porteus. 1992. Cystic fibrosis in the mouse by targeted insertional mutagenesis. Nature (Lond.). 359:211-215.

20. Facer, P., A. E. Bishop, R. V. Lloyd, B. S. Wilson, R. J. Hennessy, and J. M. Polak. 1985. Chromogranin: A newly recognized marker for endocrine cells of the human gastrointestinal tract. Gastroenterology. 89:1366-1373.

21. Sjolund, K., G. Sanden, R. Hakeanson, and F. Sundler. 1983. Endocrine cells in human intestine: An immunocytochemical study. Gastroenterology. 85:1120-1130.

22. Trezise, A. E. O., J. A. Chambers, C. J. Wardle, S. Gould, and A. Harris. 1993. Expression of the cystic fibrosis gene in human foetal tissues. Human Molecular Genetics. 2:213-218.

23. Tizzano, E. F., D. Chitayat, and M. Buchwald. 1993. Cell-specific localization of CFTR mRNA shows developmentally regulated expression in human fetal tissues. Human Molecular Genetics. 2:219-224.

24. Engelhardt, J. F., J. R. Yankaskas, S. A. Ernst, Y. Yang, C. R. Marino, R. C. Boucher, J. A. Cohn, and J. M. Wilson. 1992. Submucosal glands are the predominant site of CFTR expression in the human bronchus. Nature Genetics. 2:240-248.

25. McCray, P. B., C. L. Wohlford-Lenane, and J. M. Snyder. 1992. Localization of cystic fibrosis transmembrane conductance regulator mRNA in human fetal lung tissue by in situ hybridization. J. Clin. Invest. 90:619-625.

26. Marino, C. R., L. M. Matovcik, G. S. Gorelick, and J. A. Cohn. 1991. Localization of the cystic fibrosis transmembrane conductance regulator in pancreas. J. Clin. Invest. 88:712-716.

27. Crawford, I., P. C. Maloney, P. L. Zeitlin, W. B. Guggino, S. C. Hyde, T. Turley, K. C. Gatter, A. Harris, and C. F. Higgins. 1991. Immunocytochemical localization of the cystic fibrosis gene product CFTR. Proc. Natl. Acad. Sci. USA. 88:9262-9266.

28. Kartner, N., O. Augustinas, T. J. Jensen, A. L. Naismith, and J. R. Riordan. 1992. Mislocalization of the $\triangle F 508$ CFTR in cystic fibrosis sweat gland. Nature Genetics. 1:321-327.

29. Welsh, M. J., P. L. Smith, M. Fromm, and R. A. Frizzell. 1982. Crypts are the site of intestinal fluid and electrolyte secretion. Science (Wash. DC). 218:1219-1221.

30. Liedtke, C. M. 1989. Regulation of chloride transport in epithelia. Annu. Rev. Physiol. 51:143-160.

31. Sinaasappel, M. 1992. Relationship between intestinal function and chloride secretion in patients with cystic fibrosis. Neth. J. Med. 41:110-114.

32. Baxter, P. S., A. J. Wilson, N. W. Read, J. Hardcastle, P. T. Hardcastle, and C. J. Taylor. 1989. Abnormal jejunal potential difference in cystic fibrosis. Lancet. i:464-466.

33. Gowen, C. W., M. A. Gowen, and M. R. Knowles. 1991. Colonic transepithelial potential difference in infants with cystic fibrosis. J. Pediatr. 118:412-415. 
34. Kopelman, H., G. Forstner, P. Durie, and M. Corey. 1989. Origins of chloride and bicarbonate secretory defects in the cystic fibrosis pancreas, as suggested by pancreatic function studies on control and CF subjects with preserved pancreatic function. Clin. Invest. Med. 12:207-211.

35. Raeder, M. G. 1992. The origin of and subcellular mechanisms causing pancreatic bicarbonate secretion. Gastroenterology. 103:1674-1684.

35a. Cohn, J. A., T. V. Strong, M. R. Picciotto, A. C. Nairn, F. S. Collins, and J. G. Fitz. 1993. Localization of the cystic fibrosis transmembrane conductance regulator in human bile duct epithelial cells. Gastroenterology. In press.

36. Weizman, Z., P. R. Durie, H. R. Kopelman, S. M. Vesely, and G. G. Forstner. 1986. Bile acid secretion in cystic fibrosis: evidence for a defect unrelated to fat malabsorption. Gut. 27:1043-1048.

37. O'Grady, R. M., P. J. Wolters, K. Hildebrand, and D. R. Brown. 1989. Regulation of ion transport in porcine gallbladder: effects of VIP and norepinephrine. Am. J. Physiol. 257:C52-57.

38. Cotton, C. U., and L. Reuss. 1991. Effects of changes in mucosal solution $\mathrm{Cl}^{-}$or $\mathrm{K}^{+}$concentration on cell water volume of Necturus gallbladder epithelium. J. Gen. Physiol. 97:667-686.

39. Trezise, A. E. O., and M. Buchwald. 1989. In vivo cell-specific expression of the cystic fibrosis transmembrane conductance regulator. Nature (Lond.). 353:434-437.

40. Isomaki, A. M. 1973. A new cell type (tuft cell) in the gastrointestinal mucosa of the rat. Acta Pathol. Microbiol. Scand. Pathol. 240(Suppl.):1-35.

41. Nabeyama, A., and C. P. Leblond. 1974. "Caveolated cells" characterized by deep surface invagination and abundant filaments in mouse gastrointestinal epithelia. Am. J. Anat. 140:147-166.
42. Breuer, N., N. Kartner, J. E. Riordan, and Z. I. Cabantchik. 1992. Induction of expression of the cystic fibrosis transmembrane conductance regulator. $J$. Biol. Chem. 267:10465-10469.

43. Bargon, J., B. C. Trapnell, C.-S. Chu, E. R. Rosenthal, K. Yoshimura W. B. Guggino, W. Dalemans, A. Pavirani, J.-P. Lecocq, and R. G. Crystal. 1992. Down-regulation of cystic fibrosis transmembrane conductance regulator gene expression by agents that modulate intracellular divalent cations. $\mathrm{Mol}$. $\mathrm{Cell}$. Biol. 12:1872-1878.

44. Trapnell, B. C., P. L. Zeitlin, C.-S. Chu, K. Yoshimura, H. Nakamura, W. B. Guggino, J. Bargon, T. C. Banks, W. Dalemans, A. Pavirani, J-P. Lecoca, and R. G. Crystal. 1991. Down-regulation of the cystic fibrosis gene mRNA transcript levels and induction of the cystic fibrosis chloride secretory phenotype in epithelial cells by phorbol ester. J. Biol. Chem. 266:10319-10323.

45. Trezise, A. E. O., C. C. Linder, D. Grieger, E. W. Thompson, H. Meunier, M. D. Griswold, and M. Buchwald. 1993. CFTR expression is regulated during both the cycle of the seminiferous epithelium and the oestrous cycle of rodents. Nature Genetics. 3:157-164.

46. Bradbury, N., T. Jilling, G. Berta, E. J. Sorscher, R. J. Bridges, and K. L. Kirk. 1992. Regulation of plasma membrane recycling by CFTR. Science (Wash. DC). 256:530-532.

47. Barasch, J., B. Kiss, A. Prince, L. Saiman, D. Gruenert, and Q. Al-Awqati. 1991. Acidification of intracellular organelles is defective in cystic fibrosis. Nature (Lond.). 352:70-73.

48. Elgavish, A., and E. Meezan. 1992. Altered sulfate transport via anion exchange in CFPAC is corrected by retrovirus-mediated CFTR gene transfer. Am. J. Physiol. 263:C176-C186. 